\title{
DERIMAL SUBSTITUTE USAGE IN MANAGEMENT OF SEVERE FASCIOTOIMY WOUNDS OF MAJOR BURN PATIENTS
}

KEY WORDS: fasciotomy dermal substitutes, severe burn

\section{Percin Karakol*}

\section{Evrim Beken} Özdemir

\section{Mehmet Bozkurt}

\section{Mustafa Turan}

MD, Health Science University Bagcllar Education and Training Hospital, Department of Plastic, Reconstructive and Aesthetic Surgery, Istanbul, Turkey. *Corresponding Author

MD, Health Science University Bagcllar Education and Training Hospital, Department of General Surgery and Burn Center, Istanbul, Turkey.

MD, Health Science University Bagcllar Education and Training Hospital, Department of Plastic, Reconstructive and Aesthetic Surgery, Istanbul, Turkey. MD, Health Science University Bagcllar Education and Training Hospital, Department of General Surgery and Burn Center, Istanbul,Turkey.

Introduction: After fasciotomy in severe burn patients, complications such as infection and fluid and electrolyte loss of the opened muscle tissue are very important problems. In the late period contractures and cosmetic problems are also other problems. To decrease these complications, we used Dermal Substitutes (DS) as muscle wound covering in the early period of fasciotomy lines. Materials and Methods: Twenty-seven severely burn patients who underwent extreme fasciotomy between May 2017 and March 2020 and aged between 9 and 64 years old (mean= 33 \pm 5$)$ were enrolled in this study. Burn wounds surface area was $25 \%-92 \%$ of TBSA with a mean surface of $47 \pm 5 \%$. Seventy percent of the patients were exposed to inhalation injuries due to accident in a closed area. Results: The mean surface DSNevelia $\cap$ applied fasciotomy line area was $203 \pm 9 \mathrm{~cm} 2$. Total days of DS to integrate and mean duration time for the STSG acceptance was $21.2 \pm 2$ days. There were two partial integration failures (\%7). There was seen no adverse event due to Nevelia $₫$ usage. All patients were discharged with a mean recovery of $54 \pm 6$ days. Discussion:This type of DS is an effective weapon in the hands of a burn surgeon to reduce the possibility of infection, fluid and electrolyte loss and contracture after fasciotomy. Using skin equivalents in this way after fasciotomies also reduces secondary surgery and painful dressing rates.

\section{INTRODUCTION}

Fasciotomy is an important treatment in acute compartment syndrome [1]. Because of the swelling of the muscle tissue, primary wound closure is often not possible. In general fasciotomy incisions were either left open or as soon as possible closed. But in this case the rates of recurrent compartment syndrome and infections were unacceptably high [2]. To improve outcomes, there are different wound closure techniques, which includes delayed primary closure, immediate closure and performing a skin graft to fill the wound $[1,3]$.

Conservative treatment generally consists of daily wound cleaning and dressing change, followed by Delayed Primary Closure (DPC). DPC may help to decrease the infection rates and better cosmetic results, compared to secondary closure and skin grafts [3]. However, DPC generally is not always possible, due to infection and tissue edema [4]. If an initial operation of closure is failed, further reoperation with another closure technique and/or grafting may be required [5]. Furthermore, in any case of which closure technique is used, it is always important to understand the complications associated with the fasciotomy or the compartment syndrome, like infections, amputation, delayed bone healing, or even death $[5,6]$.

After fasciotomy, the edema slowly decreases, and the surgeon intents to approximate the fasciotomy lines. However, the skin, which should be approximate, is generally seriously affected and destroyed due to severe burn. Therefore, fasciotomy closure is an important problem in these patients. Also after fasciotomy, complications such as infection and fluid and electrolyte loss of the opened muscle tissue are very important problems. To decrease these complications, we used Dermal Substitutes (DS) as muscle wound covering in the early period of fasciotomy wounds.

Dermal Substitutes are becoming an important choice in burn |www.worldwidejournals.com treatment. DS are bio-matrices that functions like the dermal layer, acting as a barrier against infections, protecting the subcutaneous tissue from physical factors and reducing scarring. DS, which act like matrices or scaffold and support tissue build-up, improve wound healing as a result $[7,8]$. DS also provides flexibility in wound and better scar tissue formation $[9,10]$.

In this study, we present our experience using DS Nevelia ${ }^{\circledR}$ (Symatese Aesthetics, Lyon, France) for wound covering in fasciotomy lines. Nevelia consists of a two-layer, absorbable and porous matrix. The first layer of this matrix is type 1 collagen in the stabilized $2 \mathrm{~mm}$ thickness, the second part is a layer of silicone.

\section{MATERIALS-METHODS}

In this retrospective study, 27 severely burn patients [Total Body Surface Area (TBSA) >25\%] who underwent fasciotomy between May 2017 and March 2020 were included. Fasciotomy indications, complications, hospitalization and overall survival rates of these patients were analyzed. TBSA percentage was measured using the Lund and Browder chart [11]. Fasciotomy was performed when clinical signs of Compartment Syndrome come in sight.

\section{TECHNIQUE}

Complete fasciotomy technique to decompress all compartments was performed in the extremities. Two days later, after the edema subsided the DS Nevelia ${ }^{\oplus}$ was fixed on the wound layer with skin stapler, after it was cut to shape without any tension.

Then it was dressed with silver wound dressing products. The dressing was changed, DS integration was controlled every two days. The delamination of Nevelia (silicone leaf removal) was generally performed on the $20^{\text {th }}$ day. Once delaminated, the surface of the neodermis was refreshed by dermabrasion. Then meshed split-thickness skin graft was applied and the 
dressing was applied.

In this study, all grafts applied over DS were either applied as meshed 1,5-3. Skin grafts were dressed by paraffin gauze overlaid with antibacterial-soaked gauze and saline secured with bandages. Dressings were changed on the third day and then twice weekly until completely healed. Photographic records were engaged at every intervention (Fig. 1-2). Besides, a long-term clinical follow up has been recorded 1 year after healing.

Since the tissue around the wound was completely damaged and edematous, measurements were taken at the lower extremity, including the ankle malleolus level and calf level above $15 \mathrm{~cm}$, and were noted for comparisons. The same procedure was performed for the upper limb at the level of the wrist and forearm above $10 \mathrm{~cm}$.

Scar modulation was evaluated according to the Vancouver Burn Skin Score, one of the important scales for measuring skin elasticity. In Vancouver Burn Skin Scoring, skin quality was checked at 6 months after application. Patients scored for different parameters: elasticity, bendability, pigmentation and vascularization criteria were examined. Each parameter was scored between 0-3 [12].

The patients were started with ankle, arm, forearm movement exercises, and early physiotherapy to reduce the possibility of early edema, late ankylosis, and contracture. All patients were followed up with a splint only for 3 days after the procedure.

\section{Statistical Methods}

Statistical analyses were performed with the statistical software SPSS 15.0 for Windows (IBM Corp.). Results are expressed as counts with percentages for categorical variables and as mean \pm standard deviation for continuous variables.

\section{RESULTS}

\section{Patient Characteristics}

Twenty-seven patients with ages between 9 and 64 years old (mean age mean $=33 \pm 5$ shown in Table 1 were inscribed. Two out of 27 patients were female (Table. 1).

Burn cases had occurred at work and home $(70 \%$ and $30 \%$, respectively). Seventy percent of the cases were in a closed area and exposed to inhalation injuries.

Area of burn wounds were $27 \%-92 \%$ of TBSA with a mean surface of $47 \pm 5 \%$ (Table. 1 ).

\section{DS-Nevelia $®$ application}

The mean surface DS-Nevelia $₫$ applied fasciotomy line area was $203 \pm 9 \mathrm{~cm}^{2}$. Total days of DS to integrate and mean time for the STSG acceptance was $21.2 \pm 2$ days.

There seemed no adverse event related to the use of Nevelia $₫$ (Table 2). There were two partial integration failure of DS. One of these cases had a burn wound in $92 \%$ of his TBSA. He had many comorbidities like lower airway inhalation injury, pneumonia, and acute tubular necrosis. He had partial integration failure $(30 \%)$, but he was discharged with recovery.

The other case had a burn wound in $68 \%$ of his TBSA. He also had multiple comorbidities like lower airway inhalation injury, pneumonia, acute tubular necrosis, Pseudomonas and, Acinetobacter colonization in the wound. He had partial integration failure $(35 \%)$, but he was discharged with recovery (Table. 2 ).

Only 9 patients had a Vancouver score of 10 and above compared to burn percentages and were acceptable for the 6th-month results. When we look at patients with a weak burn scar score, it is seen that the rate of burning is more than $60 \%$ and there are severe burns. All patients were discharged with a mean recovery of $54 \pm 6$ days (Table. 2 ).

\section{DISCUSSION}

Fasciotomy is a limb and patient saving procedure. However, there is no consensus concerning the best method for closure of fasciotomy wounds. Different techniques have their native complications [5,6]. Also, trauma leading to the compartment syndrome may result in wound-related complications and may result in amputation or even death.

After fasciotomy, fluid and electrolyte loss and infection are very important problems in severe burn patients. However, after the DS application, fluid and electrolyte loss decreased excessively. There is no consensus concerning which technique should be used in closing fasciotomy incisions [1]. Different techniques have various complication rates and success rates $[1,4,5,13]$.

Progressive suture approximation techniques usually have low cost, but this technique causes fluid and electrolyte loss, some infectious complications, and a long time to closure. Fasciotomy attempts, which have urgency for the circulatory problem in the acute period, are followed by contractures at the scar stage, apart from wounds open to infection. Joint contractures are mostly functional problems and are events that need to be intervened in the early period in order to bring the individual back to the society, mobilize and prevent the loss of workforce.

Split-thickness skin grafting was frequently used if conservative treatment was failed or was assumed difficult because of the size of the fasciotomy wound [2]. However, in severe burn patients, the insufficiency of the graft donor site is a very important problem in the acute phase. Flap surgery for unclosed fasciotomies, tendons, and necrotic tissues that remain open can also be seen as the second stage after grafting. However, flap surgery is both costly and high morbidity operations by the patient. In one step, with this method, morbidities such as donor site morbidity are reduced, while better results can be obtained cosmetically.

DS functions as a protecting layer. It keeps the subcutaneous tissue from physical factors, acts as a barrier against infections and reduces the fluid and electrolyte loss $[7,8]$. Nevelia ${ }^{\oplus}$ is made from bovine origin specific 3-dimensional native collagen (Collagen type 1) with a large fibrous proportion to preserve cell adhesion signals and mechanical structure to support regeneration. Wound regeneration matrices should preferably be reabsorbable, and the resulting products should be non-immunogenic and toxic.

Nevelia is generally used in combination with a thin splitthickness skin graft (STSG) to recreate skin resembling the normal one in terms of appearance and function. The silicone layer is extracted after the dermal regeneration period. Then split-thickness skin graft procedure was performed. Since wound healing is a multicellular process, first of all, while the factors necessary for infection control and wound closure are in effect, then those for scar formation replace.

When STSG is used for defect repair under normal conditions, skin mobility is low and additional operations such as contracture releasing and fat injection are required many times. The main logic of such DS applications is to break the link between the outgoing signals and skin for the development of contracture and reduce fibrosis. Looking at the Vancouver Scar Scoring, it was understood that the patients, who were treated, had lighter color, less stiff, less high, and better pliability on the extremities. At the same time, less occurrence of contracture formation shows that this application yields functional and aesthetically effective 
results in fasciotomy lines. It is also effective in covering structures such as muscles, bones, tendons, and preventing them from drying out, as long as fasciotomy remains open.

Therefor DS Nevelia ${ }^{\circledR}$ also provides flexibility and better cosmetic results in a healed wound bed according to other techniques. The reason, we covered fasciotomy sites with hyaluronan coated silver hydrofiber covers after Nevelia is to take advantage of the additive antibacterial effect of silver. Another advantage of wrapping with this type of dressing is that it is easy to apply and more painless when lifting the dressing. The frequency of dressing changes is one in 2-3 days in this way. The hypergranulated tissue, that exceeds the tissue edges delays wound healing, is a brittle and bleeding tissue. By applying DS, the tissue is prevented from being granulated to exceed the wound corners.

In our clinic, we used DS Nevelia for wound covering in fasciotomy lines of severe burn patients. DS application was very helpful in decreasing the fluid and electrolyte loss. It was also successful in preventing infectious complications in fasciotomy wounds. With this technique the wound is under steady control. It is a safe and painless, for the progressive readaptation of fasciotomy wounds. Although this serie include serious cases all patients were discharged with a mean recovery of $54 \pm 6$ days.

This type of DS is an effective weapon in the hands of a burn surgeon to reduce the possibility of contracture and infection after fasciotomy. Using skin equivalents in this way after fasciotomies reduces secondary surgery and painful dressing rates. A burn is an extremely traumatic situation, so early discharge of the patient reduces costs in every sense and helps the person return to life more easily psychologically and socially. The superiority of the method is antibacterial action, in addition to mechanical protection. So as a result there seems considerable advantages to using a DS in the treatment of fasciotomy wounds in severe burn patients.

\section{CONCLUSION}

The skin in the neighbourhood of the fasciotomy line which should be approximate in severe burn patients is generally seriously burned and should be gradually excised. To manage this procedure poses some problems. To decrease complications after fasciotomy, we used Dermal Substitutes on fasciotomy lines in the early period. Nevelia is a good option that protects the wound during the closing process against toxins, microorganisms, and dehydration and at the same time reduces scar formation with its superficial silicone layer. In particular, it will be cost-effective to prevent contractures caused by prolonged tissue defects in areas close to the joints and to shorten hospital stays, and do not require flap surgery. Combining cellular therapy with biomaterials with such new-generation DS will enable progress in wound treatment and regenerative medicine.

* This research did not receive any specific grant from funding agencies in the public, commercial, or not-for-profit sectors

\section{Table 1. Subject demographics and mechanisms of burn injury.}

\begin{tabular}{|c|c|c|c|c|c|c|}
\hline $\begin{array}{l}\text { Subject } \\
\text { No. }\end{array}$ & Age & Gender & Burned areas & Mechanisms of burn injury & $\begin{array}{l}\% \text { TBSA } \\
\text { burn }\end{array}$ & $\begin{array}{l}\text { DS applicated } \\
\text { fasciotomy } \\
\text { line area }(\mathrm{cm} 2)\end{array}$ \\
\hline 1. & 18 & $\mathrm{M}$ & Lower limbs & Fire in working place with petrol indoors. & 27 & 150 \\
\hline 2. & 23 & M & $\begin{array}{l}\text { Head,Upper and lower } \\
\text { limbs and trunk }\end{array}$ & High Voltage Electric Burn Injury & 92 & 320 \\
\hline 3. & 64 & M & Lower limbs and trunk & $\begin{array}{l}\text { Fire in working place with petrol indoors. } \\
\text { Enclosed space, inhalation burn. }\end{array}$ & 50 & 240 \\
\hline 4 & 39 & M & $\begin{array}{l}\text { Upper limbs, lower } \\
\text { limbs and trunk }\end{array}$ & $\begin{array}{l}\text { Fire in working place. Enclosed space, } \\
\text { inhalation burn. }\end{array}$ & 40 & 150 \\
\hline 5 & 41 & M & Lower limbs and trunk & $\begin{array}{l}\text { Fire in working place. Enclosed space, } \\
\text { inhalation burn. }\end{array}$ & 40 & 300 \\
\hline 6 & 62 & $\mathrm{M}$ & Upper limbs and trunk & Garden fire explosion. & 30 & 150 \\
\hline 7 & 23 & $\mathrm{M}$ & $\begin{array}{l}\text { Upper/lower limbs, } \\
\text { head and trunk }\end{array}$ & $\begin{array}{l}\text { Fire in working place with explosion of the } \\
\text { water boiler. }\end{array}$ & 90 & 380 \\
\hline 8 & 45 & M & $\begin{array}{l}\text { Upper/lower limbs, } \\
\text { trunk }\end{array}$ & $\begin{array}{l}\text { Self-immolation with petrol indoors. Enclosed } \\
\text { space, inhalation burn. }\end{array}$ & 60 & 150 \\
\hline 9 & 18 & M & $\begin{array}{l}\text { Upper/lower limbs, } \\
\text { trunk. }\end{array}$ & $\begin{array}{l}\text { Fire in working place with gasoline. Enclosed } \\
\text { space, inhalation burn. }\end{array}$ & 75 & 280 \\
\hline 10 & 25 & $\mathrm{M}$ & Upper/lower limbs. & $\begin{array}{l}\text { Fire in working place with gasoline and motor } \\
\text { oil. Enclosed space, inhalation burn. }\end{array}$ & 40 & 170 \\
\hline 11 & 25 & $\mathrm{M}$ & Lower limbs & $\begin{array}{l}\text { Bonzai intoxication. House fire started by } \\
\text { cigarette falling into carpet. Enclosed space, } \\
\text { inhalation burn. }\end{array}$ & 32 & 290 \\
\hline 12 & 40 & M & $\begin{array}{l}\text { Upper/lower limbs, } \\
\text { trunk }\end{array}$ & $\begin{array}{l}\text { Burn in w3orking place with high voltage } \\
\text { electricity. }\end{array}$ & 32 & 150 \\
\hline 13 & 30 & $\mathrm{M}$ & Upper limb, trunk & $\begin{array}{l}\text { Bonzai intoxication. House fire started with } \\
\text { cigarette falling into gasoline. }\end{array}$ & 33 & 150 \\
\hline 14 & 32 & $\mathrm{M}$ & Upper/lower limbs & $\begin{array}{l}\text { Fire in working place secondary to electrical } \\
\text { fault. Enclosed space, inhalation burn. }\end{array}$ & 40 & 140 \\
\hline 15 & 45 & $\mathrm{M}$ & Upper limb, trunk & $\begin{array}{l}\text { Alcohol intoxication. House fire started with } \\
\text { cigarette falling into carpet. Enclosed space, } \\
\text { inhalation burn. }\end{array}$ & 41 & 150 \\
\hline 16 & 53 & $F$ & $\begin{array}{l}\text { Upper/lower limbs, } \\
\text { trunk. }\end{array}$ & $\begin{array}{l}\text { Suicide attempt by opening the home natural } \\
\text { gas. Home fire secondary to electrical spark. } \\
\text { Enclosed space, inhalation burn. }\end{array}$ & 45 & 150 \\
\hline 17 & 30 & $\mathrm{M}$ & $\begin{array}{l}\text { Head,Upper and lower } \\
\text { limbs and trunk }\end{array}$ & $\begin{array}{l}\text { Working place fire. Enclosed space, inhalation } \\
\text { burn. }\end{array}$ & 60 & 300 \\
\hline 18 & 24 & $\mathrm{M}$ & $\begin{array}{l}\text { Head,Upper and lower } \\
\text { limbs and trunk }\end{array}$ & $\begin{array}{l}\text { Fire in working place secondary to electrical } \\
\text { fault. Enclosed space, inhalation burn. }\end{array}$ & 60 & 140 \\
\hline 19 & 9 & $\mathrm{~F}$ & $\begin{array}{l}\text { Head,Upper and lower } \\
\text { limbs and trunk }\end{array}$ & $\begin{array}{l}\text { House fire secondary to electrical fault. } \\
\text { Enclosed space, inhalation burn. }\end{array}$ & 45 & 150 \\
\hline
\end{tabular}




\begin{tabular}{|l|l|l|l|l|l|l|}
\hline 20 & 29 & M & $\begin{array}{l}\text { Upper and lower limbs } \\
\text { and trunk }\end{array}$ & Fire in working place & 35 & 140 \\
\hline 21 & 45 & M & Lower limbs and trunk & $\begin{array}{l}\text { Fire in working place with oily dye and thinner } \\
\text { explosion. }\end{array}$ & 50 & 280 \\
\hline 22 & 23 & M & $\begin{array}{l}\text { Upper and lower limbs } \\
\text { and trunk }\end{array}$ & Fire in working place & 35 & 150 \\
\hline 23 & 32 & M & $\begin{array}{l}\text { Head, upper and lower } \\
\text { limbs and trunk }\end{array}$ & Serious electrical burn. & 65 & 280 \\
\hline 24 & 16 & M & $\begin{array}{l}\text { Upper and lower limbs } \\
\text { and trunk }\end{array}$ & Serious electrical burn. & 35 & 180 \\
\hline 26 & 28 & M & $\begin{array}{l}\text { Upper and lower limbs } \\
\text { and trunk }\end{array}$ & Serious electrical burn. & 35 & 140 \\
\hline 27 & 37 & M & $\begin{array}{l}\text { Head, upper and lower } \\
\text { limbs and trunk }\end{array}$ & Fire in working place with oil explosion. & 65 & 145 \\
\hline $\begin{array}{l}\text { Statistical } \\
\text { analyses }\end{array}$ & \begin{tabular}{l} 
mean $=$ \\
\hline
\end{tabular} & $\begin{array}{l}25 \mathrm{M}, \\
2 \mathrm{~F}\end{array}$ & $\begin{array}{l}\text { Head, upper and lower } \\
\text { limbs and trunk }\end{array}$ & Working place fire. & 50 & 150 \\
\hline
\end{tabular}

\section{M:Male, F:Female}

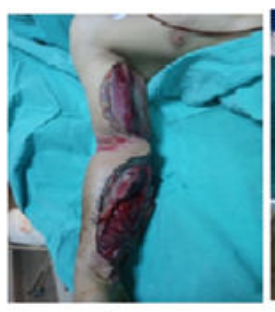

a)

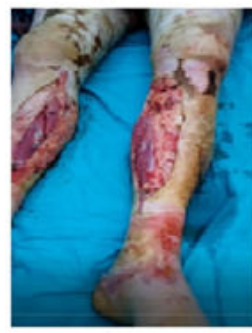

d)

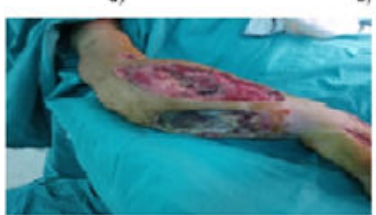

a)

b)
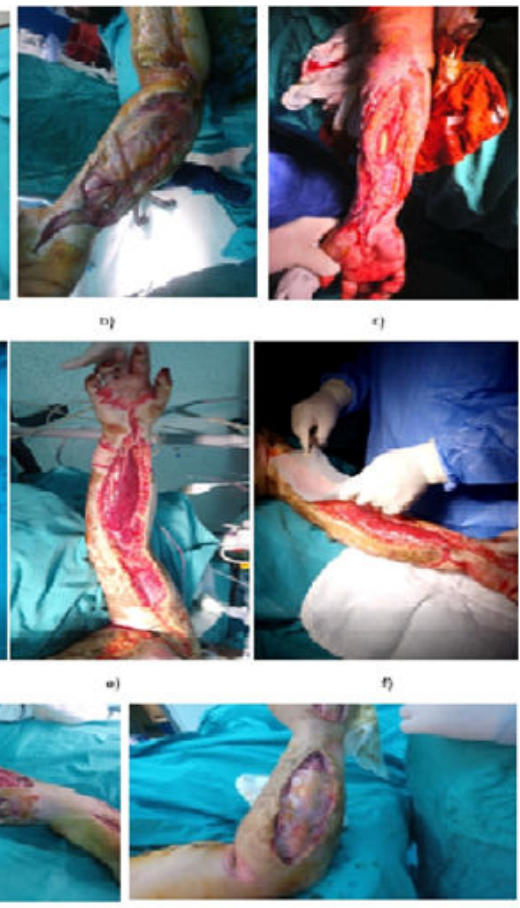

(i)

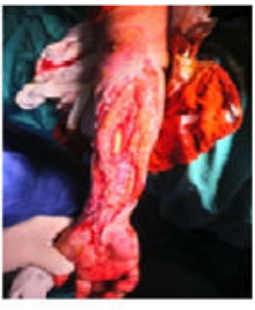

\%
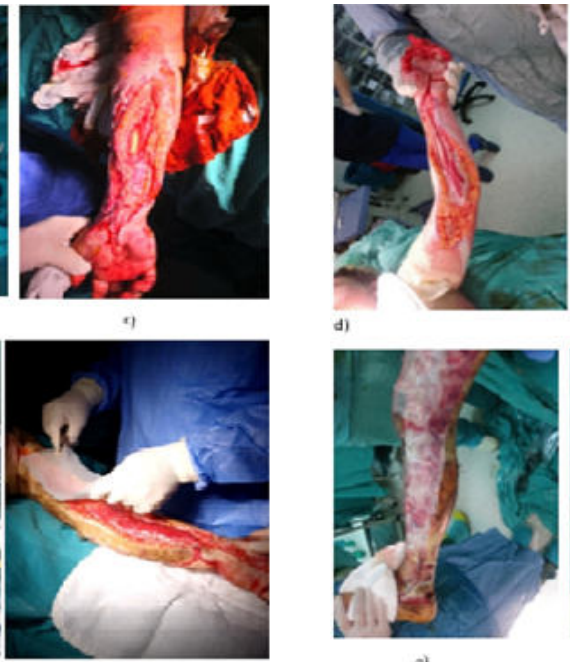
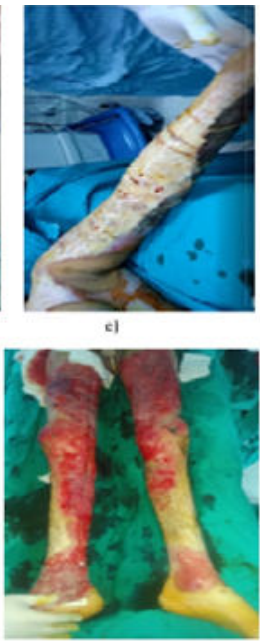
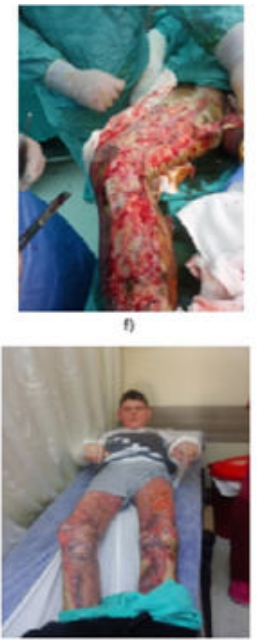

Figure 2. Case 5:28 years old man (Case 24). He burned on 50 $\%$ of his TBSA after a serious electrical burn (a). The right limb, trunk and head were burned. Then he had fasciatomy. Fasciotomy lines were applicated DS-Nevelia ${ }^{\circledR}$ (b). Split thickness skin graft was applied. He was discharged with recovery (c).

Case 6. 40 years old man (Case 8). He burned on $60 \%$ of his TBSA after self-immolation with petrol indoors. He had also inhalation injury. He underwent fascial excisions (d). Fasciotomy lines were applicated DS-Nevelia ${ }^{\circledR}(\mathbf{e})$.

Case 7: 18 years old man (Case 9). He burned on $75 \%$ of his TBSA after a working place fire with gasoline. He had also inhalation injury (f). He underwent fasciatomy. Fasciotomy lines were applicated DS-Nevelia ${ }^{\circledR}(\mathbf{g})$. Split thickness skin graft was applied (h). He was discharged with recovery (i).

\section{REFERENCES}

1. Kakagia D, Karadimas EJ, Drosos G, Ververidis A, Trypsiannis G, Verettas D. Wound closure of leg fasciotomy: comparison of vacuum-assisted closure versus shoelace technique. A randomised study. Injury 2014;45(5):890-3.

2. Jensen SL, Sandermann J. Compartment syndrome and fasciotomy in vascular surgery. A review of 57 cases. Eur JVasc Endovasc Surg 1997; 13(1):48-53.

3. Weissman O, Goldman N, Stavrou D, Barzilai L, Nardini GG, Farber N, et al. Adhesive skin closure technique for closure of fasciotomy wounds in pediatric patients: a case series.Wounds 2015;27(5): 118-222.

4. Bengezi O,Vo A. Elevation as a treatment for fasciotomy wound closure. Can J Plast Surg 2013;21(3): 192-4.

5. Velmahos GC,Theodorou D, Demetriades D, Chan L, Berne TV, Asensio J et al. Complications and nonclosure rates of fasciotomy for trauma and related risk factors. World J Surg 1997;21(3):247-52.

6. Ojike NI, Roberts CS, Giannoudis PV. Compartment syndrome of the thigh: a systematic review. Injury 2010;41(2): 133-6.

7. Lee KH. Tissue-engineered human living skin substitutes: Development and clinical application. Yonsei Med J 2000;41:774-9.

8. Pham C, Greenwood J, Cleland H,Woodruff P, Maddern G. Bioengineered skin substitutes for the management of burns: A systematic review. Burns 2007;33: 946-57.

9. Van Der Veen VC, Van Der Wal MBA, Van Leuwen MCE, Ulrich MMW, Middelkoop E. Biological background of dermal substitutes. Burns 2010; 36: 

105-21.
Hodgkinson T, Bayat A. Dermal substitute-assisted healing: enhancing stem
cell therapy with novel biomaterial design. Arch Dermatol Res 201 1;303:30115.

11. Zannis J, Angobaldo J, Marks M, De Franzo A, David L, Molnar J, et al. Comparison of fasciotomy wound closures using traditional dressing changes and the vacuum-assisted closure device. Ann Plast Surg 2009;62(4): 407-19.

12. Busche MN, Thraen ACJ, Gohritz A, Rennekampff HO, Vogt PM. Burn Scar Evaluation Using the Cutometer MPA 580 in Comparison to "Patient and Observer Scar Assessment Scale" and "Vancouver Scar Scale". J Burn Care Res.2018Jun 13;39(4):516-26.

13. Almekinders LC. Tips of the trade \#32. Gradual closure of fasciotomy wounds. Orthop Rev 1991 Jan;20(1):82-84. 